\title{
On the control of the cotton aphid, Aphis gossypii Glov. (Hemiptera: Aphididae), on cucumber in greenhouses
}

\author{
A. E. Eid ${ }^{1}$, A. H. El-Heneidy ${ }^{1}$, A. A. Hafez², F. F. Shalaby² and D. Adly ${ }^{1 *}$ (D)
}

\begin{abstract}
The objective of this study was to apply a biological control program on cucumber crop under greenhouse conditions, using biological control agents compared with insecticides to control the cotton aphid, Aphis gossypii Glover. The treatments were conducted at Dokki, Giza, Egypt, through two cucumber summer plantations in 2015 and 2016. Inspection was made once a week to determine the population density of A. gossypii, one of the major pests on cucumber. Aphid infestation occurred from week 6 to week 12 in 2015 and from week 4 to week 11 in 2016. Adults of the aphid parasitoid Aphidius colemani Viereck and larvae of the predatory coccinellid, Coccinella septempunctata $\mathrm{L}$., were released in the biological greenhouse in weeks 8, 9, and 10 in season 2015 and 7, 8, and 9 in season 2016. In the insecticide greenhouse, the recommended insecticide program was used. The cost of control in the biological control greenhouses was more than that in the insecticide one, but the yield was much higher, recording $63.88 \%$ increase in 2015 and $64.91 \%$ in 2016.
\end{abstract}

Keywords: Cucumber, Greenhouse, Aphis gossypii, Biological control, Insecticide control, Costs

\section{Background}

Aphids comprise one of the economic group of pests on cucumber plants beside mites, white flies, thrips, and caterpillars. The damage caused by aphids includes sucking the plant sap by their piercing sucking mouth parts, in addition to transmission of viral diseases from infected to healthy plants (Ali et al. 2006). In addition, aphids have high reproductive capability and rapid buildup of their population. Furthermore, aphids secrete honeydew, which prevents photosynthesis resulting in wilt and death of the plants. These factors cause economic losses in yield and quality of crops. The two common species of aphids which attack a wide range of host plants in greenhouses are the green peach aphid, Myzus persicae Sulzer, and the cotton aphid, Aphis gossypii Glover (Hemiptera: Aphididae) (Gissella et al. 2006, Ali et al. 2006).

The traditional method for controlling pests in the greenhouses is by using insecticides, although they cause

\footnotetext{
*Correspondence: daliaadly27@hotmail.com

'Biological Control Research Department, Plant Protection Research Institute, Agriculture Research Center, Giza, Egypt

Full list of author information is available at the end of the article
}

many problems such as development of insect resistance, residual effect on environment, and inhibiting the role of biological control agents (Hyun et al. 2001, Ali et al. 2006, Nicolas et al. 2012). Using biological control agents such as the aphid parasitoids, Aphidius spp., for aphid control in the greenhouse, successfully, helps to reduce dependence on insecticides alone (Fernández and Nentwig 1997). The aphid parasitoid, Aphidius colemani Viereck (Hymenoptera: Aphidiidae), has been reared on many aphid species, including A. gossypii, and is considered a potentially effective biological control agent against several economically important aphid species (Van Schelt 1994, Van Steenis 1995, Heinz 1998, Jacobson and Croft 1998, Gissella et al. 2006). The ladybird beetles such as Coccinella septempunctata L. (Coleoptera: Coccinellidae) are considered potential polyphagous predatory species that have been used on greenhouse crops such as tomato, sweet peppers, and cucumbers for controlling several pests including aphids, thrips, whiteflies, mites, and lepidopteron eggs (Omkar 2004). Biological control of pest species has traditionally focused on specific natural enemies for each 
target pest (Hoy 1994). The use of more than one natural enemy is also a recent topic in biological control, because several pests can affect the crop simultaneously. Accordingly, the combining use of natural enemies is expected to increase the efficacy of the bioagents as the specific pests can be controlled and the risk of virus infection is reduced (Lucas and Alomar 2002).

The aim of the present study was to evaluate different combinations of releasing: the aphid parasitoid, A. colemani, and the predator, C. septempunctata, to control the aphid; A. gossypii compared with a traditional insecticide application program in commercial greenhouses during the cucumber summer plantation.

\section{Materials and methods}

The experiments were carried out at the Protected Cultivation Experimental Station at Dokki, Giza, Egypt, in two commercial plastic greenhouses. The greenhouses were planted on the 18th of May 2015 and 4th of April 2016 with cucumber (Cucumis sativus L.) (variety, Baracoda).

\section{Greenhouses}

Two greenhouses were used in the experiments. The first one was divided into three sectors $(8 \times 30 \mathrm{~m}$ each), separated by white nets, fixed to the greenhouse frame, in order to insure complete isolation among the three sectors and to avoid entry of pests from one sector to another. This greenhouse was kept free from any insecticidal contamination, so it was the biological control greenhouse (BCG). The second one (same size) was $20 \mathrm{~m}$ far from the first and was used only for applying the recommended insecticide program (PAG). In the second season, a third greenhouse was added as control, without any pest control treatment (CG). In each greenhouse, five rows (being enough for planting 200 cucumber plants) were made through hoeing. Weather data inside the greenhouses were obtained from the Central Laboratory for Agricultural Climate (CLAC), Dokki, Giza, Egypt.

\section{Sources of the parasitoid and predator}

The parasitoid A. colemani was reared in the Biological Control Research Department, Agricultural Research Center at Giza, Egypt, in cloth cages $(30 \times 35 \times 35 \mathrm{~cm})$ under the laboratory conditions of $25 \pm 1{ }^{\circ} \mathrm{C}, 50-60 \%$ R.H., and 16:8 L:D photoperiod by releasing mated females of the parasitoid on wheat seedlings artificially infested with the cereal aphid species, Schizaphis graminum. After 8-9 days, formed mummies were collected, using a soft brush or by cutting the part of the plant on which the mummy was stuck on and kept in vials until emergence of parasitoid adults. Emerged adults were provided by honey droplets as food. The predatory $C$. septempunctata was obtained from the Center of Bio-organic Agricultural Services (CBAS) in Aswan.

\section{Experimental design}

The parasitoid A. colemani (parasitized aphids as mummies) and the predator $C$. septempunctata (third instar larvae) were released in the first greenhouse (BCG), applying three releasing regimes (1000 mummies in the first sector); 4 individuals of the parasitoid A. colemani $/ \mathrm{m}^{2}$ (BCG1), (2400 larvae in the second sector); 10 individuals of the predator C. septempunctata $/ \mathrm{m}^{2}$ (BCG2), (1000 mummies +2400 larvae in the third sector), and 4 individuals of parasitoid A. colemani +10 individuals of the predator C. septempunctata $/ \mathrm{m}^{2}$ (BCG3). The second greenhouse received the recommended insecticidal application program (PAG) and was used for comparison. In the three sectors (BCGs), the timing and rate of release were determined according to the aphid's infestation rate/square inch/plant. On contrary, in PAG, timing and rates of applications of pesticides followed the conventional recommendations of the Egyptian Ministry of Agriculture, depending on the assessment of pest population.

\section{Sampling}

Population density of $A$. gossypii was estimated weekly in the two experimental greenhouses for 12 successive weeks, started from the second week (1/6/2015 and 18/ $4 / 2016$ ) post cultivation date in the two cucumber summer seasons. Three leaves representing the three plant levels (upper, middle, and lower) were selected from 15 random plants directly inspected/sector/sampling date (each plant represented one replicate). In 1 in. $^{2}$, the population of the aphids was counted directly on the inspected plants by the aid of a $(\times 10)$ hand lens. A pre-count of aphids was carried out in both greenhouses before treatments. By the end of each season, the yield and costs of purchasing the parasitoids, predators, and chemical pesticides were estimated. In BCG, the estimation of yield was at an average/greenhouse in the first season, while it was by sector in the second season.

\section{Statistical analysis}

Statistical analysis of data was conducted using general linear model (GLM) and regression (Reg.) in SAS (SAS Institute 1998).

\section{Results and discussion}

Average means of minimum, maximum temperatures, and relative humidity ranged between 17.4 and $24.7{ }^{\circ} \mathrm{C}$, 41.4 and $51{ }^{\circ} \mathrm{C}$, and 30 and 55\% R.H. in 2015 and between 15 and $28{ }^{\circ} \mathrm{C}, 29$ and $47.3{ }^{\circ} \mathrm{C}$, and 24 and $60 \%$ R.H. in 2016, respectively. Statistically, significant 
negative correlations were found between each of the weather parameters and pest population, i.e., aphids' population decreased as the weather parameter increased. Plant-age factor showed a significant positive correlation between all factors. The population of aphids was low in early season and increased by growth of the plants due to the availability of plant sap in leaves even during the flowering stage, afterwards, the population decreased due to the decrease of the nutritive sap in leaves when the fruits appeared. In 2015, (Fig. 1a) in BCG, aphid infestation started from week 6 , with a rate of $0.13,0.11$, and 0.42 individual/in. ${ }^{2}$ in BCG1, BCG2, and BCG3, respectively. To avoid the increase of the aphids' population, once the aphid infestation was detected, the parasitoid A. colemani and the predator $C$. septempunctata were released three times in the 8th, 9th, and 10th weeks (Table 1). The population density of A. gossypii increased gradually to reach the peak during the 11th week in BCG1 and BCG2 and the 9th week in BCG3 [37.13, 29.86, and 46.27 individuals/in. ${ }^{2}$ in BCG1, BCG2, and BCG3, respectively (Fig. 1a)]. Van Driesche et al. (2008) reported that aphid suppression was poor when the greenhouse temperature exceeded $28{ }^{\circ} \mathrm{C}$ because such temperature is favorable to aphids and unfavorable to A. colemani (Goh et al. 2001 and Kim and Kim 2003). In PAG, aphid infestation started from week 6 in a low population, with an average of 1.733 individuals/in. ${ }^{2}$. Five insecticides Actara 25\% WG, Lannate 90\% SP, Amiral, Mospilan 20\% SP, and Vertimec 1.8\% EC (8, 15 and 22/6/2015) were applied six times (Table 1). The population density of the aphid continued to increase gradually to reach a peak (58.59 individuals/in. ${ }^{2}$ ) in the 9th week. The population of aphids increased in all treatments, except the treatment in the third sector (BCG3), which recorded a suppression in the aphid's population after the second release of the 9th week. In the PAG, the aphid population continued to increase up to the end of the season. The third treatment (BCG3) proved to be the best one where the population recorded the lowest number of aphids after releasing the parasitoid and the predator $(0.42,14.67,29.87,46.27,27.93$, 14.88, and 0 individuals/in. ${ }^{2}$ ) at the end of the season (Fig. 1a).

Statistical analysis of 2015 results, concerning differences in the population number of aphid, showed insignificant differences among the three biological control treatments; also they were insignificant between the BCG3 and PAG, but there was a significant difference between each of BCG1, BCG2, and PAG. The least significant difference (L.S.D.) recorded was (11.04 in 2016 (Fig. 1b)) in BCG treatments; aphid infestation started from weeks 4, 5 , and 6 with $0.18,0.02$, and 2.96 individuals/in. ${ }^{2}$ in BCG3, BCG2, and BCG1, respectively. To avoid the increase of the aphids' population, once the aphid infestation was detected, the parasitoid A. colemani and the predator C. septempunctata were released three times in the 7th, 8th, and 9th weeks (Table 1). The population density of A. gossypii increased gradually to reach the peaks of $42.66,31.41$, and 31.61 individuals/in. ${ }^{2}$ of leaf in the 8 th week in BCG1, BCG2, and BCG3, respectively (Fig. 1b).

In the PAG treatment, aphid infestations started from week 5 , with 0.7 individual $/$ in. $^{2}$. The same five insecticides were applied against the aphid six times $(28 / 4,5,12$, and 18/5/2016). The population density of the aphid continued to increase gradually to reach the peak of (17.64 individuals/in. ${ }^{2}$ ) in the 9th week. The population of aphids increased in all treatments, except in the treatment of the PAG, recording more suppression in the aphid's population after applying the insecticides and release of natural enemies from the 9th week to the end of the season. In 2016 summer plantation (Fig. 1a, b), a control treatment was added to the four treatments. The control treatment started with manual (artificial) infestation by placing one adult of A. gossypii on each plant in the 4th week. Number of aphids was counted weekly. The highest population of the aphid reached (60.58 individuals/in. ${ }^{2}$ ) was recorded in the 9th week. Plants received the highest population density of aphids that influenced plant growth and caused
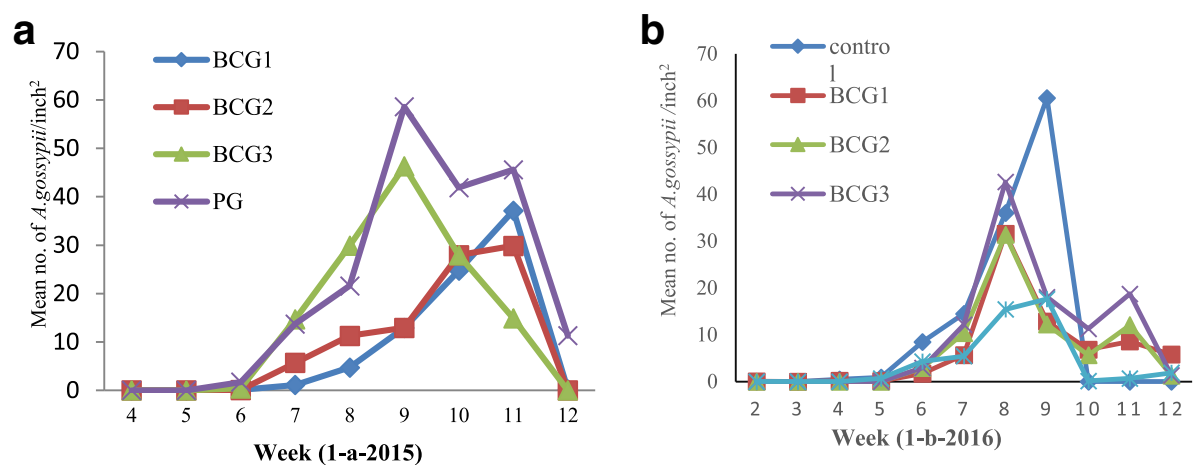

Fig. 1 a, b Mean numbers of A. gossypii/square inch in the treatments of controlling the aphid on cucumber in greenhouses in the two summer plantations, 2015 and 2016 
Table 1 Rates of releases of biological control agents and insecticides applications, costs of control treatments in cucumber greenhouses in summer plantation, 2015-2016

\begin{tabular}{|c|c|c|c|c|c|c|}
\hline \multirow[t]{2}{*}{ Week } & & \multicolumn{3}{|c|}{ Biological control applications and rates (BCG) } & \multicolumn{2}{|l|}{ Insecticide application control (PAG) } \\
\hline & & BCG1 & BCG2 & BCG3 & Pesticides & Rate \\
\hline \multirow[t]{6}{*}{2015} & 5 & & & & $\begin{array}{l}\text { Actara 25\% WG + Lannate } 90 \% \text { sp. } \\
\text { + Mospilan 20\% sp }\end{array}$ & $\begin{array}{l}30 \mathrm{~g} / 100 \mathrm{~L} / \mathrm{acre}+30 \mathrm{~g} / 100 \mathrm{~L} \\
\text { /acre }+25 \mathrm{~g} / 100 \mathrm{~L} / \mathrm{acre}\end{array}$ \\
\hline & 6 & & & & Vertimec $1.8 \% \mathrm{EC}$ & $50 \mathrm{~cm} / 100$ L/acre \\
\hline & 7 & & & & Actara 25\% WG + Amiral & $\begin{array}{l}30 \mathrm{~g} / 100 \mathrm{~L} / \mathrm{acre}+120 \mathrm{~cm} \\
/ 100 \mathrm{~L} / \mathrm{acre}\end{array}$ \\
\hline & 8 & Ac $4 / \mathrm{m}^{2}$ & $\operatorname{Cs} 10 / \mathrm{m}^{2}$ & $\begin{array}{l}A c+C s \\
4 / m^{2}+10 / m^{2}\end{array}$ & & \\
\hline & 9 & Ac $4 / \mathrm{m}^{2}$ & Cs $10 / \mathrm{m}^{2}$ & $\begin{array}{l}A c+C s \\
4 / m^{2}+10 / m^{2}\end{array}$ & Mospilan 20\%sp & $25 \mathrm{~g} / 100 \mathrm{~L} / \mathrm{acre}$ \\
\hline & 10 & Ac $4 / \mathrm{m}^{2}$ & Cs $10 / \mathrm{m}^{2}$ & $\begin{array}{l}A c+C s \\
4 / m^{2}+10 / m^{2}\end{array}$ & Vertimec $1.8 \% \mathrm{EC}$ & $50 \mathrm{~cm} / 100 \mathrm{~L} / \mathrm{acre}$ \\
\hline \multicolumn{2}{|c|}{ Total cost LE (equivalent in US \$) } & $\begin{array}{l}156 \\
(=8.7 \$)\end{array}$ & $\begin{array}{l}390 \\
(=21.8 \$)\end{array}$ & $\begin{array}{l}546 \\
(=30.6 \$)\end{array}$ & $\begin{array}{c}140 \\
(=7.8 \$)\end{array}$ & \\
\hline \multicolumn{2}{|c|}{ Cost LE/m² } & 0.65 & 1.625 & 2.275 & 0.58 & \\
\hline \multirow[t]{6}{*}{2016} & 4 & & & & Vertimec $1.8 \% \mathrm{EC}$ & $50 \mathrm{~cm} / 100 \mathrm{~L} / \mathrm{acre}$ \\
\hline & 5 & & & & Actara 25\% WG & $40 \mathrm{~g} / 100 \mathrm{~L} / \mathrm{acre}$ \\
\hline & 6 & & & & Vertimec $1.8 \% \mathrm{EC}$ & $50 \mathrm{~cm} / 100$ L/acre \\
\hline & 7 & Ac $4 / \mathrm{m}^{2}$ & Cs $10 / \mathrm{m}^{2}$ & $\begin{array}{l}A c+C s \\
4 / m^{2}+10 / m^{2}\end{array}$ & Vertimec $1.8 \%$ EC + Sulfur & $\begin{array}{l}50 \mathrm{~cm} / 100 \mathrm{~L} / \mathrm{acre}+250 \mathrm{~cm} \\
/ 100 \mathrm{~L} / \mathrm{acre}\end{array}$ \\
\hline & 8 & Ac $4 / \mathrm{m}^{2}$ & Cs 10/m2 & $\begin{array}{l}A c+C s \\
4 / m^{2}+10 / m^{2}\end{array}$ & Mospilan 20\% sp & $25 \mathrm{~g} / 100 \mathrm{~L} / \mathrm{acre}$ \\
\hline & 9 & Ac $4 / \mathrm{m}^{2}$ & $\operatorname{Cs} 10 / \mathrm{m}^{2}$ & $\begin{array}{l}A c+C s \\
4 / m^{2}+10 / m^{2}\end{array}$ & & \\
\hline \multicolumn{2}{|c|}{ Total cost LE (equivalent in US \$) } & $\begin{array}{l}156 \\
(=8.7 \$)\end{array}$ & $\begin{array}{l}390 \\
(=21.8 \$)\end{array}$ & $\begin{array}{l}546 \\
(=30.6 \$)\end{array}$ & $\begin{array}{c}167 \\
(=9.4 \$)\end{array}$ & \\
\hline \multicolumn{2}{|c|}{ Cost LE/m² } & 0.65 & 1.625 & 2.275 & 0.69 & \\
\hline
\end{tabular}

Ac A. colemani, Cs C. septempunctata

destruction of flowers and fruits, so the plants were completely destroyed starting the 10th week. Hyun et al. (2001) stated that all watermelon plants in untreated greenhouse were found dead due to the heavy infestation of A. gossypii.

Statistical analysis of 2016 results indicated insignificant difference between BCGs and control, also between
BCGs and PAG, but the difference was significant between PAG and control, as the least significant difference recorded was 7.66 .

\section{Plant height and yield}

As shown in Figs. 2a, b, in 2015 and 2016, the plant height in BCGs was taller than that in PAG by 1.19- and
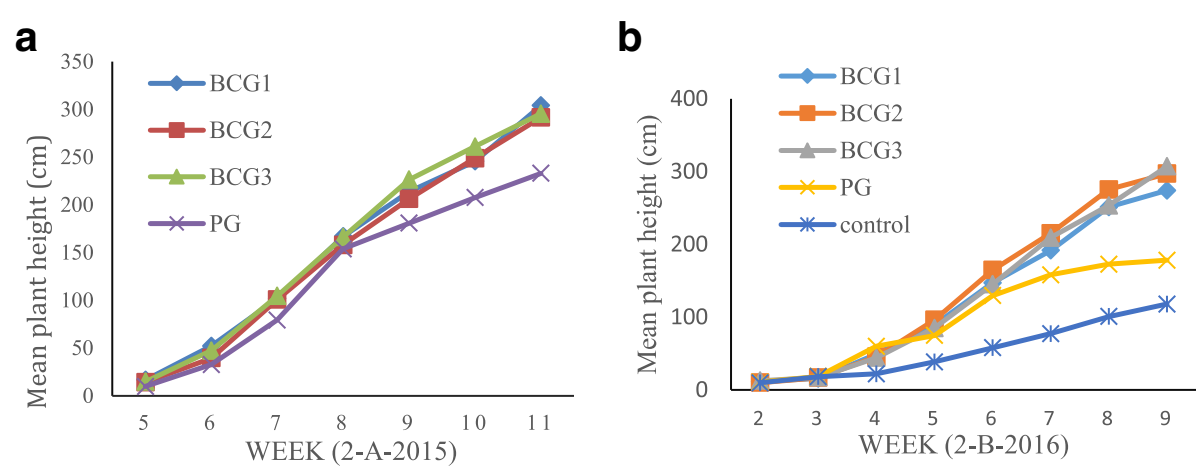

Fig. 2 a, b Mean plant height $(\mathrm{cm})$ in treatments of controlling cucumber pests in greenhouses in the summer plantation, 2015 and 2016 
1.65-folds, respectively. The plants had good growth with shinning green color in the three treatments of BCG, but most of the plants in PAG were weak and pale and had dark green color, where insecticides influence seemed to have negative effect on the heights and color of plants that may be due to the phytotoxicity. Statistical analysis of 2015 data showed insignificant differences in the plant height among the three biological control treatments, while there was a significant difference between BCGs and PAG and the least significant difference recorded was 12.77. In 2016, it showed insignificant differences among the three biological control treatments and a significant difference between each of BCG1 and BCG3 and PAG, but a significant difference was found between BCG2 and PAG, and control and the least significant difference recorded was 34.61. The cucumber yields produced from the BCGs reached $1080 \mathrm{~kg}$ (360 kg/BCG treatment on average) opposed to $130 \mathrm{~kg}$ from the PAG. The BCG produced (63.88\%) more yield than the PAG in 2015. In 2016, the yield produced was $1086 \mathrm{~kg}$ (362 kg/BCG treatment on average) from the BCGs where 249,394 , and $443 \mathrm{~kg}$ were weighed from BCG1, BCG2, and BCG3, respectively, opposed to $137 \mathrm{~kg}$ in PAG. The BCG produced (64.91\%) more yield than the PAG in 2016. Statistical analysis in 2015 revealed that the yield was significantly different between BCGs and PAG and the least significant difference recorded was 164.71 , while it showed a significant difference between BCGs and PAG and the least significant difference recorded was 49.014 in 2016 season.

\section{Cost benefit}

The cost of purchasing the biocontrol agents used in releases was the same in 2015 and 2016 (156, 390, $546 \mathrm{LE}$ in BCG1, BCG2, and BCG3, respectively). Respective costs of the insecticide applications attained 140 and 167 LE. The cost in all cases in BCGs (except BCG1 in 2016) was higher than that in the insecticide one, but the yield was higher, recording 63.88\% increase in 2015 and 64.91\% in 2016 (Table 1). A more serious problem of insecticides is that they are unjustly cheap because society ends up paying for the so-called indirect costs created by pesticide use such as death of non-target organisms, human health problems, environmental pollution, and interference with ecosystem functions (Pimentel 2009). Adly (2015) reported that the cost of using the biological control agents was relatively higher than that of the insecticides by $26 \%$ in a cucumber greenhouse (winter plantation), but there was $40 \%$ increase in the yield. Biological control in greenhouse crops proved to be very successful (Pilkington et al. 2010), but a great challenge still exists to combat pest species that currently cannot be controlled by natural enemies or to control pest species in crops where natural enemies do not establish well (Gerben et al. 2014).

\section{Conclusions}

In cucumber summer plantation, releasing rates of more than 4 individuals $/ \mathrm{m}^{2}$ of the parasitoid A. colemani and more than 10 individuals $/ \mathrm{m}^{2}$ of the predator C. septempunctata can be recommended for biological control of aphid infestation in cucumber greenhouse. Although the population of aphid did not decrease sharply (as in the chemical control) and the cost was relatively higher, the yield was significantly much higher in quantity and quality.

\section{Acknowledgements}

We are cordially thankful to Prof. Mohamed M. Abou-setta, Plant Protection Research Institute (PPRI), for his kind efforts in the statistical analysis of the study data.

\section{Funding}

There is neither conflict of interest nor financial support to the author of this research.

Availability of data and materials

All datasets are presented in the main manuscript.

Authors' contributions

All authors read and approved the final manuscript.

Ethics approval and consent to participate

Not applicable

Consent for publication

Not applicable

Competing interests

The authors declare that they have no competing interests.

\section{Publisher's Note}

Springer Nature remains neutral with regard to jurisdictional claims in published maps and institutional affiliations.

\section{Author details}

${ }^{1}$ Biological Control Research Department, Plant Protection Research Institute, Agriculture Research Center, Giza, Egypt. 'Plant Protection Department, Faculty of Agriculture, Benha University, Benha, Egypt.

Received: 11 May 2018 Accepted: 17 July 2018

Published online: 03 August 2018

\section{References}

Adly D (2015) Comparative study of biological and chemical control programs of certain cucumber pests in greenhouses. Egypt. J. Biol. Pest Cont 25(3):691696 Proceeding of $4^{\text {th }}$ international conference, ESBCP, Cairo, Egypt, 19-22 October 2015

Ali G, Madanlar N, Yoldaş Z, Ersin F, Tüzel Y (2006) Pest status of organic cucumber production under greenhouse conditions in İmir (Turkey). Türk. entomol. Derg 30(3):183-193 ISSN 1010-6960

Fernández C, Nentwig W (1997) Quality control of the parasitoid Aphidius colemani (Hym.: Aphidiidae) used for biological control in greenhouses. J Appl Ent 121:447-456

Gerben JM, Jude B, Oscar A, Barbara LI, Luciana T, Les S, Eric P, Felix LW (2014) Approaches to conserving natural enemy populations in greenhouse crops: current methods and future prospects. BioControl 59(4):377-393 Gerling, D. 1990. Whiteflies: their bionomics, Pest status and management. Andover, Hants: Intercept Ltd 
Gissella MV, David BO, James RB (2006) Efficacy assessment of Aphidius colemani (Hymenoptera: Braconidae) for suppression of Aphis gossypii (Homoptera: Aphididae) in greenhouse-grown chrysanthemum. J. Econ. Entonol 99(4): 1104-1111

Goh H, Kim J, Han M (2001) Application of Aphidius colemani Viereck for control of the aphid in the greenhouse. J Asia-Pacific Entomol 4(2):171-174

Heinz KM (1998) Dispersal and dispersion of aphids (Homoptera: Aphididae) and selected natural enemies in spatially subdivided greenhouse environments. Environ Entomol 27:1029-1038

Hoy, M.A. 1994. Parasitoids and predators in management of arthropod pests, in: Introduction to insect pest management, R.L. Metcalf and W.H. Luckmann, 4 129-198, John Wiley \& Sons, ISBN 978-0-471-58957-0, New York

Hyun GG, Jeong HK, Han MW (2001) Application of Aphidius colemani Viereck for control of the aphid in greenhouse. J. Asia-Pacific Entomol 4(2):171-174

Jacobson RJ, Croft P (1998) Strategies for the control of Aphis gossypii Glover (Hom.: Aphididae) with Aphidius colemani Viereck (Hym.: Braconidae) in protected cucumbers. Biocontrol Sci. Technol 8:377-387

Kim Y, Kim J (2003) Biological control of aphids on cucumber in plastic greenhouses using banker plants. Korean J Appl Entomol 42:81-84

Lucas E, Alomar O (2002) Impact of presence of Dicyphus tamaninii Wagner (Heteroptera: Miridae) on whitefly (Homoptera: Aleyrodidae) predation by Macrolophus caliginosis (Wagner) (Heteroptera: Miridae). Biol Control 25:123-128

Nicolas D, Thielemans T, Herbener M, Rosemeyer V (2012) The use of a mix of parasitoids to control all aphid species on protected vegetable crops. Integrated control in protected crops, Mediterranean climate. IOBC-WPRS Bulletin 80:261-266

Omkar PA (2004) Predaceous coccinellids in India: predator-prey catalogue. Orient Insects 38(1):27-61

Pilkington L, Messelink G, van Lenteren JC, Le Mottee K (2010) "Protected biological control" - biological pest management in the greenhouse industry. Biol Control 52(3):216-220

Pimentel D (2009) Environmental and economic costs of the application of pesticides primarily in the United States. In: Peshin R, Dhawan AK (eds) Integrated pest management: innovation-development process. Springer, Dordrecht, pp 89-111

SAS Institute (1998) SAS user's guide, statistics. SAS Institute, Cary, NC

van Schelt, J. 1994. The selection and utilization of parasitoids for aphid control in greenhouses. Proceedings of the section experimental and applied entomology of the Netherlands entomological society (N.E.V. InProc. Exp. Appl. Entomol., NEV Amsterdam. 5: 151-157

Van Driesche RG, Lyon S, Sanderson JP, Bennett KC, Stanek EJ III, Zhang R (2008) Greenhouse trials of Aphidius colemani (Hymenoptera: Braconidae) banker plants for control of aphids (Hemiptera: Aphididae) in greenhouse spring floral crops. Fla Entomol 91(4):583-591

Van Steenis MJ (1995) Evaluation of four aphidiine parasitoids for biological control of Aphis gossypii. Entomol Exp Appl 75:151-157

\section{Submit your manuscript to a SpringerOpen ${ }^{\circ}$ journal and benefit from:}

- Convenient online submission

- Rigorous peer review

- Open access: articles freely available online

- High visibility within the field

- Retaining the copyright to your article

Submit your next manuscript at $\boldsymbol{\nabla}$ springeropen.com 